\title{
Old Testament spirituality in the gospel of John
}

\begin{abstract}
Author:
Dirk G. van der Merwe ${ }^{1}$

\section{Affiliation:}

${ }^{1}$ Department of Christian Spirituality, Church History and Missiology, University of South Africa, South Africa

\section{Correspondence to:} Dirk van der Merwe

Email:

vdmerdg@unisa.ac.za

Postal address:

189 Kotie Ave, Murrayfield

0184, South Africa
\end{abstract}

Dates:

Received: 05 Feb. 2013

Accepted: 18 Sept. 2013

Published: 23 May 2014

How to cite this article: Van der Merwe, D.G., 2014, 'Old Testament spirituality in the gospel of John', Verbum et Ecclesia 35(1), Art. \#837, 9 pages. http://dx.doi. org/10.4102/ve.v35i1.837

Note:

This article is an edited version of an invited chapter for the Festschrift dedicated to Fr. Frédéric Manns. It is published here with the permission of the Festschrift editor.

\section{Copyright:}

(C) 2014. The Authors. Licensee: AOSIS OpenJournals. This work is licensed under the Creative Commons Attribution License.
The majority of early Christian documents are saturated with Jewish thought. Although Second-Temple Judaism did include a certain amount of diversity, when the Gospel of John was written in different phases during the latter half of the 1st century, the written Torah was a fixed part of Jewish Scripture. In this research, I endeavour to point out how Torah themes saturate the Prologue of the Gospel of John and also how these themes create a certain spirituality amongst its readers. A positive feature of Old Testament imagery and themes is that they are polysemantic, which made it easy for the writers of New Testament documents to reinterpret the Old Testament in the light of Jesus Christ. The author of the Gospel of John also made use of significant characters, themes and imagery, all taken from the Torah. In doing so, he created new spiritualities amongst the readers of the Gospel of John to endorse the identity, reality and a certain image and experience of the unseen God (1:18) of the Old Testament through Jesus Christ. The spirituality in the Gospel of John is bound up with a real God interacting with real people in real situations.

\section{Introduction}

One of the major tasks of biblical theology is to understand the Old Testament as foundational to New Testament proclamation. ${ }^{1}$ The writers of the New Testament never felt free to withdraw from the heritage of faith in the Scriptures of the Hebrews. ${ }^{2}$ Instead, they asserted that the Scriptures of the Hebrews had to be reinterpreted in the light of Jesus Christ. ${ }^{3}$ In doing so, they discovered the basic foundations of their proclamation and a new (Christian) spirituality which they also tried to establish amongst their readers (cf. Morgan 1957:155).

The Gospel of John is saturated with themes and concepts coming from the Torah, ${ }^{4}$ so much so that it is impossible to explore all this in a single essay. I therefore had to select which particular themes and concepts to discuss. Although the title of this research is Old Testament spirituality in the Gospel of John, my intention is to take a demarcated text from the Prologue (1:14-18) of the Gospel of John and try to explore the spirituality in it that relates closely to parallel themes in the Torah. ${ }^{5}$ The purpose of this exercise is to point out how the message of the Gospel of John is embedded in the Torah and how the fourth evangelist attempts to let his readers re-experience Torah spirituality. However, this spirituality is now in a new vestment, in the resurrected Christ. The aim of this argument is to point out that, in Christ, a new epoch has begun.

The reason for choosing this topic is that early Christian spirituality is a relatively new academic discipline that adds new perspectives, meaning and understanding to New Testament texts. It adds, in the process of the reading and interpreting of the Novum Testamentum, the lived experiences of the resurrected Christ and the God of the Old Testament in the lives of the early 1.Wucherpfennig (2003:488) relates the first 14 verses in the Prologue to the Torah.

2.Roth (1987:8) is convinced that the narrative code of the Gospel of John lies hidden in the Old Testament. See also Rivkin (1984:11) and Westermann (1994:7), who states: 'es kommt die neue Situation hinzu, daß einerseits die jüdische Exegese die Schriften der Tora ohne jegliche Berücksichtigung der Schriften des Neuen Testaments auslegt und anderseits das NeueTestament bei christlichen Exegeten häufig ganz von der jüdischen Tradition her verstanden wird.' See also Westermann (1968).

3.Cf. Weltzen (2011:38). Steyn (2012) proposes coining a new term in canonical Biblical scholarship, namely, retrodiction (reading backwards) rather than prediction. Cf. also Morgan (1957:155-165) and Pentiuc (2002:37-54). Carr (2002:32) states: 'To read a Jewish text as a prediction or anticipation of the Christ event is to make an implicit claim about its original or deepest meaning that is intensely problematic.' Tenney (1963b:300-308) discusses briefly how the Gospel of John is saturated with Old Testament references and suggestions.

4.Wolfgang (1987:6-29), Kanagaraj (2001:33-60), Casselli (1997:15-41), Wright (2005:302), Wucherpfennig (2003:488), Westermann (1994:7). Creation (1:1-3); theophany at Sinai (1:14-18); a new Covenant (1:14-19); wisdom motif (1:11); Moses (1:17); glory (1:14); grace and truth $(1: 14,16$, 17). Other Toraic themes in the Gospel of John are - John 3: The lifting up of the serpent (3:14); John 4: grace and truth $(1: 14,16,17)$. Other Toraic themes in the Gospel of John are - John 3: The lifting up of the serpent (3:14); John 4:
Well of Jacob; John 4: I AM (Ex 3:14); John 5: Sabbath - working and resting; John 6: Moses - manna; John 6-10: feasts; John 7: living Well of Jacob; John 4: IM (Ex 3:14); John 5: Sabbath - working and resting; John 6: Moses - manna; John 6-10: feasts; John 7: living
water, Abraham; John 8: children of Abraham; John 9: disciples of Moses; John 13: footwashing. The Fourth Evangelist also refers to water, Abraham; John 8: children of Abraham; John 9: disciples of Moses; John 13: footwashing. The
and discusses all 10 commandments in fragments throughout the Gospel. Cf. also Smith (1962:329).

5.This is due to space constraints. The Gospel of John is saturated with Old Testament themes. The vast majority of these themes come from the Pentateuch. See the works of Morgan (1957:155-165), Hanson (1991:95-97), Wolfgang (1987:6-29), Kanagaraj (2001:33-60), Casselli (1997:15-41). Cf. also Sanders (1975:372-390), Hengel (1990:19-41), Wright (2005:302-305). Reasons for such a saturation are the following: most of the Gospel was probably written prior to 70 CE (in Jerusalem to Jews) but was finally edited in Ephesus by the end of the 1st century. Early Christianity was very much embedded in Judaism (see Dunn 2003) and can therefore be regarded as a mutation of Judaism. 
Christian writers. These writers also want their readers to re-experience in their lives the lived experiences of the early Christians regarding the resurrected Jesus and the God of the Old Testament. These religious lived experiences they tried to be re-experienced in the lives of their readers. Their faith in God and the resurrected Christ and their experiences of the resurrected Christ constitute a new spirituality in the early Christians writers that must have influenced their writing of the early Christian documents. Despite this, very little research has been done on this aspect of the early Church. ${ }^{6}$ My purpose in this essay, therefore, is to point out how the fourth evangelist incorporates into the Johannine Prologue the spirituality experienced when reading the Torah.

In this essay, I start by defining the meaning and determining the content and the extent of the influence of Torah in SecondTemple Judaism to reflect on how it is understood in Judaism in the 1st century CE and how I shall use it in this essay. I then discuss Toraic themes that emerge from the selected text and explain how the spiritualities that emerge from reading the Torah influenced the fourth evangelist.

\section{The Torah in Second-Temple Judaism \\ What is the Torah?}

For the Jews at the time of the New Testament, the 'Heilige Schrift war für sie an erster Stelle die Tora. Darauf folgten die Propheten' (Wucherpfennig 2003:486). Canonically, the Torah is a balanced combination of story and law: story and law belong together, and Torah therefore means both. Sanders (1975:372) explains this according to the diagram in Figure 1.

Torah may simply refer to the Pentateuch. Torah may also have the extended meaning of divine revelation generally (Sanders 1975:380). It is a symbol for the identity of Jews (just as Christ has symbolic meaning for the identity of Christians). Torah never lost or loses the dual character of muthos-ethos (Sanders 1975:381) noted above (Sanders 1975:373). Chilton and Neusner (1995) argue:

The Torah is the literal word of God in all details, so that, therefore, all who wish to be 'Israel' must keep the Torah precisely as it is worded. The Torah expresses God's will and purpose for humanity. (p. 1)

\section{Content - fixed in Second-Temple Judaism}

The canonisation of the Old Testament was a historical process that took place in the early believing communities over a period in time between the 6th century BCE and the 2nd century CE. A good part of the Pentateuch and the Former and Latter Prophets seems to have been in existence and accepted as authoritative in some circles by as early as the end of the Persian period (Grabbe 2003:162-163). According to Hegg (2007:2), the tradition of public Torah

6. Hurtado (2005:183) points out in a lengthy discussion 'that New Testament scholarship tends to ignore or give little attention to religious experiences in describing and analysing the features of Jesus and earliest Christianity'.

7.See Keener (2003:364-369), who relates the pre-existence of the Torah with that of the Logos.
Torah $\left[\begin{array}{l}\text { Muthos -- gospel - story - identity -- haggadah } \\ \text { Ethos ---- laws ---- ethics - life style - halachah }\end{array}\right.$

FIGURE 1: Torah configuration.

reading derives from the earliest times of the history of Israel. In the historical account of the return of the exiles from Babylon, a detailed account is given of the public reading of the Torah (Neh 8:1-8). ${ }^{8}$ This makes the reading of the Torah and prophets in the 1st-century synagogues a certainty. The Torah was also probably read according to some fixed schedule. It is therefore reasonable to deduce that the Torah was fixed (Grabbe 2003:157) by the time that the Gospel of John was written (in phases over a period of time) (Du Rand 1997:103-107) during the latter half of the 1st century.

\section{Diversity in Second-Temple Judaism}

Second-Temple Judaism was not a monolithic religion. Between the last century BCE and the 1st century CE, it was an extremely heterogeneous, diversified religion. ${ }^{9}$ Some Jewish parties in Second-Temple Judaism emphasised the muthos and others the ethos aspect of Torah. ${ }^{10}$ However, only two Jewish parties survived after the destruction of Jerusalem and the temple in $70 \mathrm{CE}$ : the Pharisees, who went on to establish what became known as Rabbinic Judaism, and the Christians of the early church. Both these parties may be regarded as 'two daughters' of the 'mother faith' of SecondTemple Judaism. After $70 \mathrm{CE}$, the two parties diverged and went in quite different directions (Sanders 1975:373).

These different directions make particular sense in the light of the Figure 1. 'Rabbinic Judaism, following the emphasis of Pharisaism, stressed the ethos or halachah aspect of Torah' (Sanders 1975:373). Christianity emphasised the muthos or haggadah aspect. Neither, however, emphasised or absolutised one to the exclusion of the other. The Torah was for both a combination of gospel and law (Sanders 1975:374).

The haggadic-story aspect of Torah provided early Christians with a strong argument for their claim regarding the authority of Christ and his place in the work of God. According to Sanders, this is the basic reason why Torah as Heilsgeschichte plays a more prominent role in the New Testament than does Torah as law (Sanders 1975:374). Chilton and Neusner $(1995: 4,5)$ states that, for at least the 1st century of Christianity, their only revealed Scripture was the same Torah that the Hebrews had received and which the Hebrews regarded as the revealed teaching of God. As far as possible, both Jews and Christians appealed to the Torah to

8. Hegg surveyed numerous historical materials to give us a picture of how the Torah and prophets were read during 1st-century synagogue services.

9.Cf. Sanders (1975:375). See also Chilton and Neusner (1995:1, 2, 5) and Pentiuc (2002:38-42). In another of his publications, Sanders (1989:66) again agrees that diversity existed in Rabbinic Judaism but that 'the differences had been overemphasized in previous scholarships'.

10.Jewish pluralism in the period of the Second Temple is well attested in the early Jewish literary complex represented by the Apocrypha, Pseudepigrapha, Dead Sea . Scrolls, Elephantine Papyri, Tannaitic literature and others (Sanders 1975:373). engel (1973:1-12) contends that, from the middle of the 3rd century BCE, al of Judaism was Hellenistic to a greater or lesser extent with stirrings of clear opposition in Ben Sira, Wisdom speculation, the Hasidic movement and perhaps the Essenes. 
validate and strengthen their faith. They both also studied the Torah to explain it. ${ }^{11}$

If we focus on the Gospel of John, it becomes evident that, for the fourth evangelist, the reading of the Torah had certain implications for the early Christian believer. ${ }^{12}$ Whatever implications may be drawn from the observations made in this essay, we can say that, for the fourth evangelist, Jesus Christ is the embodiment of the Torah and is in this sense its telos. ${ }^{13}$ This is certainly evident in the Prologue of John.

Finally, if the fourth evangelist is in fact reflecting on and reinterpreting the Torah, his method certainly has implications for his existential circumstances as well as for our own contemporary hermeneutical approach. His reading of the Torah is consistently and thoroughly Christocentric. He is aware of the interpretive traditions that grew up around the Old Testament in the light of the person, ministry, death and resurrection of Jesus as the Messiah (cf. Casselli 1997:17-18).

In this subsection, I tried to argue that, in spite of diversity in Second-Temple Judaism, the Torah was already fixed by the middle of the 1st century CE. The early Christians were very much acquainted with the content and meaning of the Torah. The early Christians therefore knew the Torah and would recall the detail of the Toraic events and teaching as well as the spirituality (lived experience) it evoked when they heard or read it in the Gospel of John.

\section{Spiritualities evoked by the Torah and the Johannine Prologue Spirituality}

Before we explore the spiritualities evoked by the reading of the Torah in the Johannine Prologue, we first have to define spirituality, which paved the way for the veneration ${ }^{14}$ of Jesus.

\section{A lived experience}

The term spirituality, as used in this essay, refers to the lived experiences of the early Christians (Weltzen 2011:47).

11.The involvement of the early Christians in practices in the Synagogue during the 1st century becomes evident from the three texts in the Gospel of John which


$12: 42 ; 16: 2)$

12.It is also vital for an understanding of the Jewish background to the Gospel of John to remember that the fourth evangelist, more than any other New Testament writer, was directly influenced by the Masoretic text (and not the LXX) as can be seen in his quotations from the Old Testament. Where the LXX and Hebrew text seen in his quotations from the Old Testament. Where the LXX and Hebrew text
disagree (six times), he favours the Masoretic text in rendering the Old Testament quotation. His use of the Old Testament at these crucial moments in our Lord's life that the life of Jesus was according to Scripture (Morgan 1957:157; cf. also Roth 1987:7).
that the life

13.According to Sherry Brown (2010:245), the traditional Judaism of the 1st century CE is the principal background for Johannine thought. The Old Testament is the essential literary backdrop for the fourth evangelist. Old Testament references and themes are woven into both the structure and the words and deeds of Jesus, even when explicit Old Testament citations are lacking (see Hanson 1991:234-253). Fo Raimond Brown (1975:59-60), some of the background of the thought of Jesus can be found in the theology of the Pharisees of his time as is evident from the later rabbinic writings. He adds that the thought of Jesus in the Gospel of John is also 'expressed in a peculiar theological vocabulary and outlook' that is consonant with the Jewish Oumran group in Palestine. Hence, behind the theological with the Jewish Qumran group in Palestine. Hence, behind the theological conceptualisation of the fourth evangelist as well as the context of the Johannine community lies a complex combination of various forms of religious thinking and expression that were current in Judaism and Palestine during the life of Jesus and
the generation after his death.

14.The verb veneration (of Jesus) is used in this essay with the semantic denotation of worship, adoration and honour.
Schneiders (2000:252, 254) defines spirituality as 'the experience of consciously striving to integrate one's life in terms not of isolation and self-absorption, but of selftranscendence toward the ultimate value one perceives'. For the Christian believer, this ultimate value is God. According to Almond (1982:166-167), who has undertaken an investigation of mystical experiences, one's religious experience and 'the content that informs it' are connected. Almond (1982:168) also emphasises the fact that we must allow for 'those experiences which goes beyond and are at odds with the received context'. He explicitly points to powerful religious experiences that 'may lead to the creative transformation of a religious tradition' and that 'are capable of generating new interpretations of the tradition' (Almond 1982:168). Later in his research, he discerns that, although previously held religious beliefs may well shape the nature of mystical experiences, it is also true that such experiences may be decisive in the formulation or revision of doctrinal frameworks (Almond 1982:183).$^{15}$ Thus, the cognitive content of religious revelations can probably be a reformulation or reconfiguring of religious convictions (Hurtado 2005:186).

This phenomenon is evident in the fourth evangelist's use of extraordinary vocabulary in the second half of the Prologue (1:14-18), a vocabulary that gives new and extended Toraic meanings to the following words and phrases: word, dwell, grace and truth, grace upon grace, one and only, reveal, no one has seen God. By giving Christological meaning to Toraic phenomena and events, the fourth evangelist tries to transform and transfer the spirituality experienced when reading the Torah into Christian spirituality. ${ }^{16}$ This attempt comes to fruition in 1:14-18, in the fourth evangelist's veneration of Jesus.

\section{The veneration of Jesus - the Torah redefined}

Hurtado (2005) is convinced that powerful revelatory religious experiences were crucial causative factors that produced significant religious innovations that mark early Christianity. The initial step in this phenomenon was the emergence of firm convictions that the crucified Jesus had been raised from the dead and exalted to heavenly glory and rule. These convictions are already evident in the earliest Christian writings. In these documents (of which the Gospel of John is part), these convictions are treated as a sacred tradition that goes back to the foundation of the Christian movement (Hurtado 2005:192). If we consider the resurrection appearances as crucial in generating earliest Christian assertions, these experiences must have involved unusual and specific elements that helped shape the exceptional convictions that mark the early Christian proclamation (Hurtado 2005:193). As historical sources,

15.Gunkel (1979:100) warns against attempts to make the religious thought of Paul simply a borrowing from other sources: 'The theology of the great apostle is the expression of his experience, not of his reading.

16.Different spiritualities can be generated through how a text is written and read. It can be constituted through the themes, concepts, nouns and verbs chosen as well as through the rhetoric of the author and the semantics and coherence of the text. A different spirituality is also created when the fourth evangelist uses the Masoretic text instead of the LXX (see footnote 28). The verbs used in the the Masoretic text instead of the LXX (see footnote 28). The verbs used in the
Prologue (1:14-18) help to create the experience of events (pitch his tent, have seen, revealed). 
these narratives seem eager 'to affirm the continuity of the Jesus encountered in the appearances with the Jesus who died' (Hurtado 2005:194). There are good reasons to think that, whatever the details, the primary effect upon those who experienced these encounters was an inherent sense that the crucified Jesus had been clothed with divine glory $(17: 5,24)$ (cf. Hurtado 2005:194).

The most striking innovation in earliest Christianity, therefore, is the treatment of the glorified Jesus as an object of cultic devotion and veneration in ways and terms that seemed otherwise reserved only for the God of Israel (Hurtado 2005:197). The fourth evangelist therefore uses the opportunity to attach his lived experiences of the resurrected Christ to the Torah in order to venerate him. ${ }^{17}$

The above discussion explains how the lived experiences of the early Christians of the resurrected Christ led to his veneration. Both the lived experiences and veneration of the resurrected Christ contributed to the reformulation or reconfiguring of religious convictions regarding the Torah and Jesus Christ ( $\lambda$ ó ${ }^{\circ} \varsigma$ [word]). The spirituality experienced when reading the Torah is renewed and redefined in Christ. God is no more to be found in the Torah. According to the fourth evangelist, God is now to be found only in Jesus Christ, as I shall point out in the following section. In this section, the distinction and recreation of spiritualities will be postulated by comparing John 1:14-18 with Exodus 33-34.

\section{Toraic spirituality in the Johannine Prologue Toraic themes in the Johannine Prologue}

In this subsection, I want to explore how the fourth evangelist uses Toraic themes in the Johannine Prologue in order to create related, though different, spiritualities. The spiritualities originally experienced in the real historical circumstances during the Hebrew's wandering in the desert are now recalled in a different context. Roth (1987) argues the following:

The work of John is a selective and inverted, narrative re-writing of 'The Law' and 'The Prophets' of the Hebrew Bible, climaxed in the portrayal of the new creation through the gift of the Spirit by the risen Jesus. (p. 7)

Before exploring the text, it is necessary briefly to explain the historical Toraic events which the fourth evangelist had in mind when he wrote the Gospel.

Introduction - events in Exodus 33-34: When reading the Prologue (especially 1:14, 18), one becomes aware that it is saturated with Toraic themes ${ }^{18}$ which the fourth evangelist has formed into a coherent unit. ${ }^{19}$ Boismard convincingly points to the fitting together of John 1:14-18 and

17. Such devotion to and veneration of Jesus caused the followers of Jesus to encounter tensions concerning their faith. The earliest direct evidence comes from Paul himself, who was once vigorously involved in opposing the new movement of Jewish Christians (Hurtado 2005:68). See also Hultgren (1976:97-111).

18.Tabernacle, glory of God, full of grace and truth, law, Moses, nobody has seen God, son of God, revelation.

19.See Van der Watt (1991:93-126) with regard to the coherent structural exposition of Johannine theology (cf. also Loader 1984:188-216; Tenney 1963a:117-125).
Exodus $33-34 .^{20}$ Before comparing these two texts, it is appropriate to consider the episodes recounted in Exodus 3334 because these would be the events recalled by those who were thoroughly familiar with the history of the Hebrews when they heard or read certain Toraic vocabulary in the text of John 1:14-18.

The historical events leading to what happened in Exodus 33-34 are the following: ${ }^{21}$ God had concluded with the Hebrews a covenant which he sealed by the gift of the Law (Ex 19-20). Unfortunately, the Hebrews broke the covenant. They gave themselves up to idolatry in building the golden calf. This consequently led to Moses breaking the table of the Law (Ex 32). God rejected these unfaithful people. God then ordered them to continue on their way to the promised Land although he would not accompany them because of their unfaithfulness (Ex 33:1-3). Moses insists that God should rethink his decision. His presence is indispensable to protect Israel against their enemies whom they will meet along the way (33:15-16). God agrees to do so, but Moses insists on visible proof of his presence: Moses then asks to see God (33:17-18). God consequently answers Moses that it is impossible for a human being to see God (33:19-23). Nevertheless, God agrees to Moses' request as far as possible. Moses will not see God's face. He will only see him from behind. In the course of this theophany, God reveals to Moses his name, that is, who he is (34:1-7). Finally, God dictates the Law a second time to Moses, who puts it down in writing (34:10-28). After Moses had come down from the mountain, he conversed with God in the tent at times. At other times, he returned to the Hebrews to tell them everything which God has commanded them (34:29-34) (Boismard 1993:94).

From this brief analysis, the following comparable events, events that occur both in John 1:14-18 and Exodus 33-34, will be investigated: Jesus and Moses, divine presence, glory, grace and truth and, finally, revelation.

Jesus and Moses: ${ }^{22}$ Given that Moses plays a highly significant role in the Torah, especially in the events recounted in Exodus 33-34, and given that, in the Gospel of John, Moses is explicitly compared with Jesus, it is reasonable to introduce a comparison between Jesus and Moses, as reflected in 1:17, with the assumption that, in the Gospel of John, Jesus is a prophet like Moses. Although a direct citation from Deuteronomy 18:18-19, 'I will raise up for them a prophet $\ldots{ }^{\prime}{ }^{23}$ does not occur in the Gospel of John, this theme of Jesus as the new Moses runs through the Gospel of John. It is evoked first by the title Prophet which is given to Jesus

20.Boismard (1993:94-98), Carson (1991:130), Malone (2007:319), Ridderbos (1991:55). See also the focused essay of Hanson (1991:90-101) and more commentaries.

21.In describing the events in Exodus 33-34, I strongly rely on the work of Boismard (1993:94-96).

22.For Malone (2007:319), whether or not 'John intends a (positive) comparison or a (negative) contrast between Moses and Jesus, he is clearly proclaiming the superiority of the glory, grace and revelation now made available through the Son my judgement, explored briefly in terms of lived experiences.

23.The quotations in this essay come from the New Revised Standard Version (NRSV). 
(6:14; 7:40, 52; cf. also 1:21). Jesus is not any prophet, but the Prophet par excellence who must come into the world (6:14). This Prophet can only be 'the one of whom Moses has written in the law' $(1: 45 ; 5: 46)$. He is a prophet like Moses ${ }^{24}$, and God has promised in Deuteronomy 18:15-22 that he would be sent (Boismard 1993:66-67).

As early as the Prologue of John (1:17), the fourth evangelist associates Jesus with Moses: The law indeed was given through Moses; grace and truth came through Jesus Christ. ${ }^{25}$ I want to use this verse to lay the table for further exploration. Although there is certainly some sort of implied contrast at work in this verse, the precise nature of the contrast is ambivalent. There is nothing in the formal structure of the passage that demands an antithetical relationship. ${ }^{26}$ The fourth evangelist finds in Jesus not a contrast to Moses but the eschatological fulfilment in Jesus of all that Moses represented. According to the miracle ( $\sigma \eta \mu \varepsilon i o v ~[s i g n])$ narratives incorporated in the gospel, Jesus is more than orthodox Judaism (the Jewish tradition [2:1-11] and religion [2:13-22]), more than heterodox Judaism (Jn 4), more than man (equal to God, Jn 5), more than Moses (Jn 6, 9) and, finally, more than death (Jn 11). This characterisation of Jesus (more than) by the fourth evangelist contextualises his comparison of Jesus with Moses.

In the fourth gospel, an epochal shift in understanding occurs in the attachment of the Torah (via Moses) to the person of Jesus Christ. The old order, including the centrality of the Torah, is giving way to the new order with a new centre, a person who is the incarnation of all Torah, and a person who is both promised and expected (Casselli 1997:37). Carson (1991) (see also Casselli 1997:38) notes that one of the characteristic features of the way in which the gospel of John alludes to the Old Testament:

$\ldots$ is the manner in which Jesus is assumed to replace Old Testament figures and institutions. He is the one of whom Moses wrote, the true bread from heaven, the true Son, the genuine vine, the tabernacle, the serpent in the wilderness, the Passover. (p. 98)

Casselli (1997:38) summarises the above discussion well in his statement 'that Jesus is also Torah itself, Torah incarnate'.

In conclusion, comparing Jesus with Moses is not a matter of contrast but a matter of substitution and fulfilment. ${ }^{27}$ The fourth evangelist presents Jesus in a way that is consistent

24.In the Gospel of John, there are 13 references to Moses: $1: 17,45 ; 3: 14 ; 5: 45,46$ $6: 32 ; 7: 19,22,23 ; 8: 5 ; 9: 28,29$. This shows the importance of Moses for the fourth evangelist. In most of these texts (7 times), Jesus is compared to Moses.

25.Cf. Boismard (1993:1-68) for a thorough discussion of 'Jesus, the Prophet like Moses'.

26.Schnackenburg (1968:277), for example, says, 'Thus John sees no absolute contradiction between Moses who gave the law (at God's command), and Jesus Christ who brought grace and truth.' Brown (1975:16) adds the understandin that 'the gift of the Law through Moses is an instance of hesed and 'emet, an that 'the gitt of the Law through Moses is an instance of hesed and 'emet, an understanding that truly reflects the Old Testament outlook. The theory that 1:17 contrasts the absence of enduring love in the Law with presence of enduring ove in Jesus Christ does not seem to do justice to John's honorific reference to Moses' (145, iii 14, v. 46). Carson (1991:32) and Borchert (2001:23) agree with
Schnackenburg and Brown.

27.This fulfilment-and-replacement theme is developed further in the fourth gospel (cf. Jn 1:51; 2:19-21; 4:21-26; see also Lincoln 2005:104). with the Judaisms ${ }^{28}$ of his day, which were profoundly Torah centred (Casselli 1997:16). Comparing Jesus with Moses in 1:17 plays a key role in the way in which Jesus is characterised as

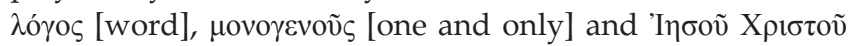
[Jesus Christ] and the spirituality this evokes. This variety of characteristics used to describe Jesus links up with important thematic threads in the spirituality of John - threads that can be characterised as the Johannine spirituality of salvation and revelation (cf. Weltzen 2011:26). In this comparison, the fourth evangelist assumes basic Jewish perspectives without question, and yet he reshapes them for his own theological purpose to create new lived experiences (spiritualities) with his readers that relate and recall the spiritualities of the Torah (Casselli 1997:17). By comparing Jesus to Moses, the fourth evangelist wants to reform the spiritualities evoked when reading the Torah in order to find new lived experiences in Jesus.

Experienced divine presence: One of the main themes that underscore the Exodus account is that of divine presence (Ex 33:15-16; 34:9). God accompanies his people during their wandering in the desert. As the Hebrews lived in tents, Moses, at the order of God, had a tent built which would be the dwelling of God during the Exodus (Ex 36:8-19). On completion, God took possession of this tent: 'Then the cloud covered the tent of meeting, and the glory of the LORD filled the tabernacle' (Ex 40:34) (Boismard 1993:94-95). In this tent, Moses was to accommodate the two tablets of the covenant document. Moses was not able to enter the tent of meeting because the cloud had settled upon it, and the glory of the Lord filled the tabernacle (Boismard 1993:95). For the Hebrews, this scene evoked the spirituality of God's presence amongst them (cf. Ex 33:14, 15; 40:34, 35).

In John 1:14, the Prologue describes the way in which God makes himself present in a new era through a new intermediary: 'And the Word became flesh and lived among us' (1:14). In 1:1, it is written that this Word is God. It is therefore God who comes to dwell amongst humans by becoming flesh. When the fourth evangelist refers to dwelt,

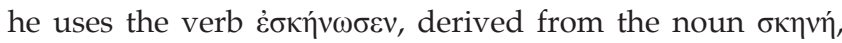
which means tent (cf. Louw \& Nida 1993:§7.9, 83, §7.17). One can then translate the verse thus: 'He pitched His tent among us. ${ }^{29}$ The Logos dwells amongst the Johannine believers as God (Yahweh) dwelt in the midst of his people during the Exodus (Boismard 1993:95-96).

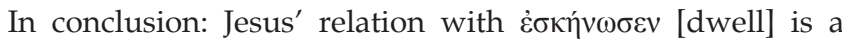
matter of presence. God became physically present through Jesus just as he was physically present through the tabernacle

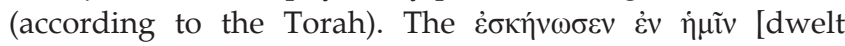
amongst us] will later be replaced by the Paraclete. In John 14-16, Jesus promises his disciples that he will not leave them comfortless. He promises them the Paraclete. According to

28.See subheading Diversity in Second-Temple Judaism of this essay about the diversity in 1st century Judaism. Cf. also Barrett (1978:33).

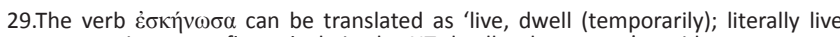
or camp in a tent; figuratively in the NT dwell, take up one's residence, come to reside (among)' (Jn 1:14) (Friberg, Friberg \& Miller 2000:350). Danker (2000:929) translates it as 'an expression of continuity with God's "tenting" in Israel'. 
17:26, a new lived experience of God's presence is constituted by the resurrected Christ (Logos). In a new mode of existence, he will be present amongst his followers in future.

Have seen his glory: In the Exodus story, God agrees to journey with his people, but Moses asks for proof of his presence (cf. Ex 24:15-17). He asks God to show him his glory (33:18). God refuses this request by saying: 'you cannot see My face; for no one shall see Me and live' (Ex 33:20). Then God nonetheless agrees (up to a point) to carry out Moses' request (Ex 33:21-23) (Boismard 1993:95). Although God does indeed come to Moses in a theophany, what he gives to Moses is quite specifically not the sight of his beauty, his glory or his Presence. What he gives to Moses is a description, not of what he looks like but of who he is. ${ }^{30}$ Although Moses was not allowed to see the glory of God, the Hebrews have seen the glory of God in Moses, whose face shone after he came down from the mountain where he had been talking with God (34:29-35) and where he had received the law.

What was impossible for Moses became possible for those who lived during the time (and after) of Jesus because the Logos became incarnate. The fourth evangelist therefore

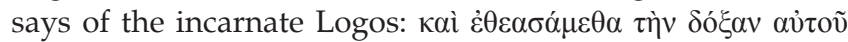
[and we have seen his glory] (1:14). This is glory which he holds from the Father. As in Exodus, the Word came to God's people. According to the fourth evangelist, when the Logos tabernacles amongst his people, his glory is revealed (Keener 2003:405). The fourth evangelist regards various acts of selfrevelation as evidence of Jesus' glory. Jesus' signs reflected his glory $(2: 11 ; 11: 4,40) .{ }^{31}$ However, the ultimate expression of glory is the complex of Jesus' death $(12: 16,23,28$; 13:31-32), resurrection and exaltation (cf. 7:39; 12:16; 17:1, 5) (Cook 1984:295). Jewish readers, with such a complex of concepts, would have known that glory refers to a revelation of God's identity as implied in Exodus 33-34 (Keener 2003:410). ${ }^{32}$

The Greek verb $\dot{\varepsilon} \theta \varepsilon \alpha \sigma \alpha \dot{\mu} \mu \varepsilon \theta \alpha$ [see] relates semantically to 'the light that shines ( has the sense of luminosity according to 1:14, it is employed

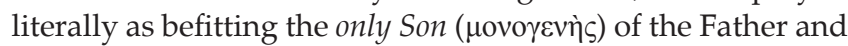
can be understood here in terms of the physical and spiritual senses: ${ }^{33}$

- Physical senses: They were the witnesses of his work on earth and particularly of the signs whereby he revealed his glory (cf. 1:50f.; 2:11; 11:40; 17:4).

- Spiritual senses: Spiritual senses are constituted through the Paraclete $(3: 3,5 ; 14: 26 ; 15: 26 ; 16: 13,14)$ and faith (see and/or hear).

30.Durham (1987:452). Kuyper (1964:6) states that חֶֶֶ, [grace and truth] are nouns to describe action.

31.See Ridderbos (1991:53). Signs and glory were already connected in the LXX. See Numbers 14:22. With regard to Moses, cf. Exodus 16:7 and Numbers 14:22. See also Sirach 45:3.

32.Cf. also Ridderbos (1991:51). See Boismard (1993:4-98) for a detailed discussion about the relationship between Exodus 33-34 and John 1:14-18.

33.Friberg et al. (2000:95) defines it as 'see, look at, behold; a verb of seeing, generally with special meanings: (1) with attentive regard behold, look at, look over, see ( $\mathrm{Mt}$ 22:11; $1 \mathrm{Jn} 1: 1$ ); (2) with a supernatural impression watch, behold, gaze on' (Jn $1: 14,32)$. Louw and Nida (1993:278) indicates that 'to observe something with $1: 14,32)$. Louw and Nida (1993:278) indicates that to observe something with
continuity and attention, often with the implication that what is observed is continuity and attention, often with the implication that what
something unusual- "to observe, to be a spectator of, to look at"'.
It is only when people have encountered Jesus physically or through hearing the Gospel and consequently perceiving the



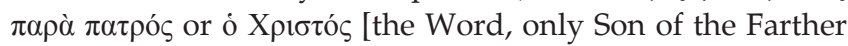
and of the Christ]) that a new and different lived experience is realised (see Jn 9). This means that people could also have perceived his glory in his crucifixion after the resurrection had occurred (Jn 17:1-5).

In conclusion, the glory of Jesus is a matter of identity. His glory is also the glory of God (see Jn 1:1-2; 17:1-5). Only a salvation spirituality can create a revelation spirituality to create


$\delta$ ó $\xi \alpha v \alpha$ ขoṽ [and we have seen his glory], they recalled the glory of God at Sinai and linked it to the glory of Christ who reflects the glory of God. Thus, in the glory of Jesus, they would have re-experienced ( $\dot{\varepsilon} \theta \varepsilon \alpha \sigma \alpha \dot{\mu} \mu \varepsilon \theta \alpha$ [see]) the glory of God.

Experience of God's redemptive act - grace and truth: Why did God forgive the unfaithful Hebrews at Sinai? In Exodus 33:19, God promised Moses to proclaim his Name before Moses - to reveal to Moses his character. He does this during the theophany narrated in Exodus 34:6. When God passed near Moses, who was hiding himself in the cleft of a rock, he proclaimed that he was 'The LORD, the LORD, a God merciful and gracious, slow to anger, and abounding in steadfast love and faithfulness' (Boismard 1993:96). ${ }^{34}$

In this Exodus narrative, the meaning of this formula would be that God was bound to show himself as good toward his people on account of the covenant that he had made with them. ${ }^{35}$ The Hebrews rebelled against God when they broke the covenant by making the Golden Calf. Because God is faithful, he, in his love, agreed to renew the covenant. The faithfulness of God is inseparable from his willingness to forgive the faults and the unfaithfulness of the Hebrews (cf. Mi 7:18-20). Hence, the Hebrews experienced at Sinai the salvation of God which was simultaneously an act of revelation of his character. The readers of the Gospel of John experienced in the comparison between Jesus and Moses the sensibility of their salvation through Jesus Christ ( $\lambda$ óros

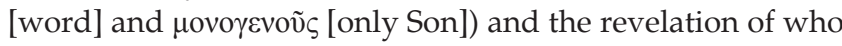
God really is.

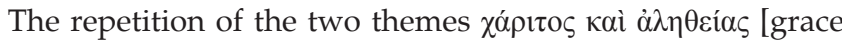

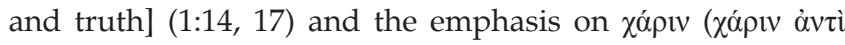

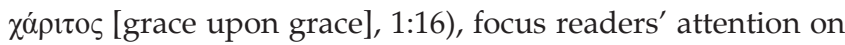
the active role that God played through Jesus Christ. It is because of God's initiative that Jesus was incarnated and that

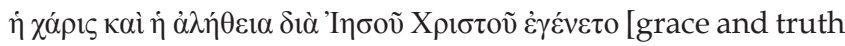
came through Jesus Christ]. The lived experience of God's involvement (merciful and gracious ... faithfulness) with the Hebrews is now extended to the early church through $\dot{\eta} \chi \alpha$ ors

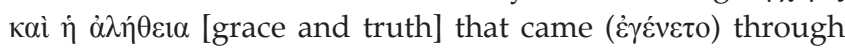

34.See Ridderbos (1991:54; also Boismard 1993:96; Durham 1987:452) for a discussion on the relatedness between the Hebrew (Ex 34:6) and Greek (Jn 1:14, 17) texts.

35.In his covenant with the Hebrews, God has established his relationship of "הסיד [grace and truth]. It is God's compassion and grace that forgive sin, and it is his [grace and truth] that characterise his relationship with those forgiven. 
Jesus Christ. ${ }^{36}$ These words are more than concepts: they refer to the faithful and redemptive act ${ }^{37}$ of God as demonstrated in Christ (cf. Kuyper 1964:19).

In conclusion, the $\chi \alpha \dot{\alpha} \rho \tau \varsigma_{\varsigma} \kappa \alpha \grave{\alpha} \dot{\alpha} \lambda \eta \theta$ cías [grace and truth] that came through Jesus is a matter of character. The grace and truth of God as narrated in the Torah, which God showed to the Hebrews, have been personified in Jesus Christ. It reflects the character of God in Exodus 34:6 and John 1:14, 17, a God who liberates people and who reveals himself through Jesus Christ. When God proclaimed his identity to Moses, it moved Moses to worship God (Ex 34:8; cf. also 33:10). Moses' lived experience of worshipping God is equally expressed by the

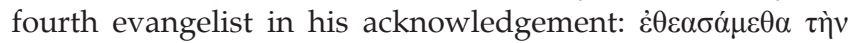

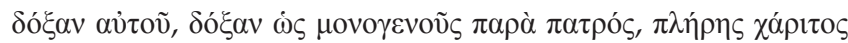

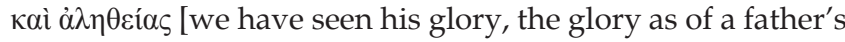
only son, full of grace and truth]. In the resurrected Christ, the Johannine community experienced God's glory, God's mercy and God's grace.

No one has ever seen God versus has made him known: The readers of the Gospel would have known that the Torah speaks of seeing God in different ways (cf. Ex 33:11, 20; Nm 12:8; Dt 18:16). Its main point, however, is that God cannot be an object of direct observation for anybody, not even for Moses (Ex 33:19-23). The human person cannot even continue to exist in the unveiled presence of God. Moses' experience of God at Sinai therefore resonates with the statement in John 1:18 that 'no one has ever seen God' ${ }^{38}$ However, this has now been changed in Jesus Christ.

In 1:14, the presence of the divine and in 1:18 the revelation or explanation ( $\dot{\varepsilon} \xi \eta \gamma \eta \dot{\sigma} \sigma \tau$ [reveal]) of the divine is attributed

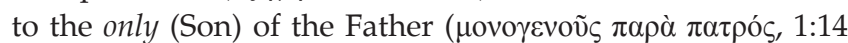

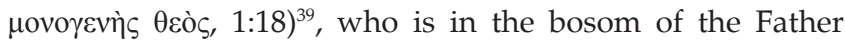
and who was with ( $\left.\pi \rho \mathrm{s}_{,}, 1: 1,2\right)$ the Father. The extent of the perfect revelation of the Father by the Son is inferred

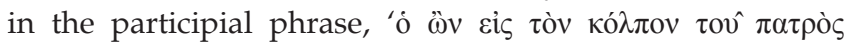

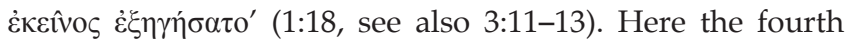
evangelist employs figurative language to emphasise the absolute intimacy between the Father and the Son (cf. Keener 2003:424; Newman \& Nida 1993:27; Carson 1991:135; Köstenberger 2004:49). ${ }^{40}$ Holding an object to one's bosom declares the specialness of that object, and indicates an intimate connection. The intimate connection between the

36. Hanson (1976:21) is convinced that Exodus 34:6b was deliberately translated as $\pi \lambda \eta \dot{\rho} \eta \varsigma$ $\chi \alpha$ ́́ as $\pi \lambda \eta \rho \eta \zeta ~ \chi \alpha \rho \tau$ o
evangelist. He also feels that the fourth evangelist translated it from the Hebrew. The content of this vision is described in terms of a revelation of God.

37. Both words describe action, according to Kuyper (1964:6).

38.Borgen (1968:145) states that 1:18 echoes Exodus 33:20. According to Borgen, a significant modification was made to the theophany referred to in Exodus $33: 20$. Moses was not allowed to see the face of God. The fourth evangelist adds that one heavenly figure has had this full vision of God, the divine Son, the one who is from God.

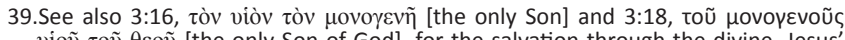

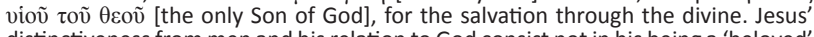
distinctiveness from men and his relation to God consist not in his being a 'beloved'

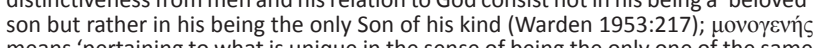
means 'pertaining to what is unique in the sense of being the only one of the same agrees with Louw and Nida's definition: 'of what is the only one of its kind of class, unique.'

40.Keener (2003:424-425); see also the $\delta$ óg $\alpha$ [glory] motif in 17:1-5.
Father and Son is not only relational but also exists in terms of their shared nature and similar role. ${ }^{41}$ The Prologue thus culminates in a rehearsal of Jesus' deity, closing an inclusio that began with 1:1 (Keener 2003:425).

The ambiguous verb $\dot{\varepsilon} \xi \eta \gamma \eta \dot{\sigma} \sigma \tau$ [reveal] ${ }^{42}$ is therefore used to refer to the way in which the Son revealed the Father in the world. Elsewhere in the New Testament, it means 'to rehearse fact' or 'to recount a narrative' (Lk 24:35; Ac 10:8; 15:12, 14; 21:19) (Carson 1991:135). ${ }^{43}$ The fourth evangelist uses a verb, which is almost a terminus technicus in Greek literature ${ }^{44}$ for the declaration of divine secrets by an oracle or a priest (Barrett 1978:141; Brown 1975:18; Lindars 1981:99). This would imply that, through his life and exaltation, Jesus has shown us the way to God. The Light has revealed God. He unveils the character of God absolutely. This verb falls into the semantic category of light, visibility, seeing, revealing, making known, et cetera. The verb $\dot{\varepsilon} \xi \eta \gamma \eta \dot{\sigma} \sigma \tau \mathrm{o}$ [reveal] suggests that the Son fully interprets the Father. ${ }^{45}$ The fourth evangelist can therefore proclaim that the only Son of the Father can explain him. ${ }^{46}$

In conclusion, the $\dot{\varepsilon} \xi \eta \gamma \eta \dot{\sigma} \sigma \tau$ [reveal] of God that came through Jesus is a matter of revelation. The spirituality created by the fourth evangelist through this statement is related but opposite to the spirituality that Moses experienced and the Hebrews read about in the Torah, namely, that no one has or can ever see God. This spirituality of seeing God could only be experienced when, in a relationship, the Light (1:3) enlightened the believer. However, it still remains true that no one can see the face of God. Just as God did not allow Moses to see his face, so the Johannine believer can only see God through the lens of his only Son.

In the new connections of Jesus with the Toraic themes in the Prologue, the fourth evangelist communicates his lived experiences of the resurrected Christ with his readers. Here we see how his powerful religious experiences led to the creative transformation of the Torah tradition and spiritualities and consequently generated new interpretations of that tradition and spiritualities. His spirituality (lived experience) of the new mode of the presence of the resurrected Christ $(17: 26)$ in the community was decisive for the reformulation

41.See Carson (1991:134): 'the Word was simultaneously God and with God.'

42.Louw and Nida (1993:99, §8.39) point to the intimacy in the relationship as 'an association of intimacy and close affection' and in $448, \S 34.18$ as 'to be closely and intimately associated with the implication of strong affection' (see also Phillips 2006:218). The verb $\dot{\varepsilon} \xi \eta \gamma \eta \dot{\sigma} \sigma \tau$ o [reveal] is related to the English term exegesis. In $2006: 218)$. The verb $\dot{\varepsilon} \xi \eta \gamma \eta \dot{\eta} \sigma \tau$ [reveal] is related to the English term exegesis. In
Josephus, it is the technical term for the exposition of the Law by the rabbis. The object of the exposition from the Logos-Son is the Father. This exegesis is peculiarly authoritative by virtue of the unity of the Son with God, expressed in the phrase authoritative by virtue of the unity of the Son with God, expresse
'who is in the bosom of the Father' (Beasley-Murray 2002:15).

43.Louw and Nida (1993:411, §33.201): 'to provide detailed information in a systematic manner'; 'to inform, to relate, to tell fully'; $(340, \S 28.41)$ : 'to make fully and clearly known'; 'to make something fully known by careful explanation or by clear revelation'.

44.Barrett (1978:141) points out that this usage corresponds with a major Greek use of the word. According to Schnackenburg (1968:279), in Josephus, it is 'the technical term for interpretation of the law as practised by the Rabbinate'.

45.Köstenberger (2004:50) points out that, in its Lucan occurrences (Lk 24:35; Ac 10:8 $15: 12,14 ; 21: 19)$, this verb regularly means 'to give a full account' in the sense of



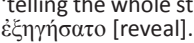

46.Schnackenburg (1968:279) refers to this as salvific revelation 
and revision of Toraic doctrinal frameworks. The fourth evangelist's religious experiences, which influenced and changed his religious convictions, contributed to a reformulation or reconfiguration of his cognitive content, and this reformulation finds expression in the Prologue.

\section{Conclusion}

As I said at the beginning of this article, most early Christian documents are saturated with Jewish thought. In this research essay, I discussed how the Gospel of John is saturated by the spiritualities that were evoked when the Torah was read. The fourth evangelist has taken Old Testament imagery and themes from the Torah to create a related but new spirituality with a view to endorsing the identity, reality and a certain image and experience of the unseen God (1:18) of the Old

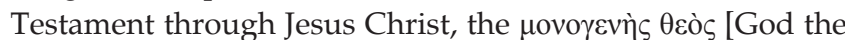
only (Son)].

With these allusions, the fourth evangelist gives his experiences a typical deep meaning hidden below the surface of the text. The prologue tells the story of the life of Jesus as a new written Torah. He thus gives the reader a key for the understanding of the Gospel. In the Torah, Moses is described as the one who received the word of God at Sinai. In the Prologue, the fourth evangelist reported the Word of God as being carnally tangible in Jesus Christ, newly revealed to human beings. In Jesus Christ, the Torah (Word of God) is renewed in a unique way. The fourth evangelist, who wanted to generate new lived experiences of the divine,

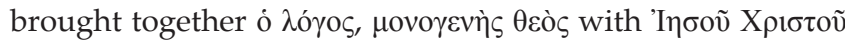
[the Word, God the only (Son) with Jesus Christ] within the literary environment of the Torah.

Two fundamental questions that remain are whether the spirituality in John gave rise to the integration of the Torah in the Prologue, or is this rather a case of pre-understanding? Did the pre-understanding of the Torah contribute to the birth of this spirituality in the Gospel of John as the result - impact - of a spiritual reading process of the Torah? Conceivably, both possibilities are valid. If this is true, we have an example of a circular interactive process in which the fourth evangelist (and the implied reader) attributed meaning to the text whilst, at the same time, the text has had a transforming spiritual impact and lived experience on the reader (cf. Weltzen 2011:34).

\section{Acknowledgements Competing interests}

The author declares that he has no financial or personal relationship(s) that may have inappropriately influenced him in writing this article.

\section{References}

Almond, P.C., 1982, Mystical experience and religious doctrine: An investigation of the study of mysticism in world religions, Mouton, Berlin. PMCid:PMC2040617

Barrett, C.K., 1978, The gospel according to St. John: An introduction with commentary and notes on the Greek text, S.P.C.K., London.
Beasley-Murray, G.R., 2002, John Word, Incorporated, Dallas. (Word Biblical Commentary, vol. 36).

Boismard, M-E., 1993, Moses or Jesus. An essay in Johannine Christology, Fortress Press, Minneapolis.

Borchert, G.L., 2001, John 1-11, Broadman \& Holman Publishers, Nashville. (New American Commentary).

Borgen, P., 1968, 'God's agent in the Fourth Gospel', in J. Neusner (ed.), Religions in antiquity: Essays in memory of Erwin Remsdell Goodenough, pp. 137-148, Brill, Leiden. (Studies in the history of religions, Supplements to Numen 14).

Brown, R.E., 1975, The gospel according to John. A new translation with introduction and commentary, vol. 1, Geoffrey Chapman, London.

Brown, S., 2010, Gift upon gift: Covenant through word in the Gospel of John, Pickwick Publications, Oregon.

Carr, D.M., 2002, 'Ordinary Christology: Reflections from an Old Testament perspective on the theological significance of Jesus', Union Seminary Quarterly Review 56(3/4), 30-47.

Carson, D.A., 1991, The gospel according to John, APOLLOS, Leicester

Casselli, S.J., 1997, 'Jesus as eschatological Torah', Trinity Journal 18(1), 15-41.

Chilton, B. \& Neusner, J., 1995, Judaism in the New Testament: Practices and beliefs, Routledge, New York.

Cook, W.R., 1984, 'The "Glory" motif in the Johannine corpus', Journal of the Evangelical Theological Society 27(3), 291-297.

Craghan, J., 1983, Love and thunder: A spirituality of the Old Testament, Liturgical Press, Collegeville.

Danker, F.W., 2000, Greek-English Lexicon of the New Testament and other early Christian literature, 3rd edn., University of Chicago Press, Chicago.

Du Rand, J.A., 1997, Johannine perspectives: Introduction to the Johannine writings, part 1, Orion, Halfway House.

Durham, J.I., 1987, Exodus, Word Books, Waco.

Friberg, T., Friberg, B. \& Miller, N.F., 2000, Analytical lexicon of the Greek New Testament, Baker Books, Grand Rapids. (Baker's Greek New Testament library, vol. 4).

Dunn, J.D.G., 2003, The theology of Paul the apostle, T\&T Clark, London.

Grabbe, L.L., 2003, Judaic religion in the second temple period: Belief and practice from the exile to Yavneh, Routledge, New York.

Gunkel, H., 1979, The influence of the Holy Spirit: The popular view of the apostolic age and the teaching of the apostle Paul: A biblical-theological study, Fortress Press, Philadelphia. PMid:510453

Hanson, A.T., 1976, 'John i.14-18 and Exodus xxxiv', New Testament Studies 23, 90101. http://dx.doi.org/10.1017/S0028688500008420

Hanson, A.T., 1991, The prophetic gospel: A study of John and the Old Testament, T\&T Clark, Edinburgh.

Hegg, T., 2007, 'The public reading of the Scriptures in the first century synagogue', Torah Resource 1-16, viewed 09 September 2012, from http://www. torahresource.com/EnglishArticles/TriennialCycle.pdf

Hengel, M., 1973, Judaism and Hellenism: Studies in their encounter in Palestine during the early Hellenistic period, SCM Press, London.

Hengel, M., 1990, 'The Old Testament in the Fourth Gospel', Beiträge zur historischen Theologie 12, 19-41.

Hultgren, A.J., 1976, 'Paul's Pre-Christian persecutions of the church: Their purpose, locale, and nature', Journal of Biblical Nature 95, 97-111. http://dx.doi. org/10.2307/3265475

Hurtado, W., 2005, How on earth did Jesus become a God?: Historical questions about earliest devotion to Jesus, Eerdmans, Grand Rapids.

Kanagaraj, J.J., 2001, 'The implied ethics of the Fourth Gospel: A reinterpretation of the Decalogue', Tyndale Bulletin 52(1), 33-60.

Keener, C.S., 2003, The Gospel of John: A commentary, vol. 1, Hendrickson, Peabody. Köstenberger, A.J., 2004, John, Baker Academic, Grand Rapids.

Kuyper, L.J., 1964, 'Grace and truth: An Old Testament description of God, and its use in the Johannine Gospel', Interpretation 18(1), 3-19.

Lincoln, A.T., 2005, The gospel according to St John, Continuum, New York. (Black's New Testament Commentary, vol 4).

Lindars, B., 1981, 'John and the synoptic gospels: A test case', New Testament Studies 27, 287-294. http://dx.doi.org/10.1017/S0028688500006688

Loader, W.R.G., 1984, 'The central structure of Johannine Christology', New Testament Studies 30, 188-216. http://dx.doi.org/10.1017/\$0028688500013758

Louw, J.P. \& Nida, E.A., 1993, Greek-English Lexicon of the New Testament based on semantic domains, United Bible Societies, New York.

Malone, A.S., 2007, 'The invisibility of God: A survey of a misunderstood phenomenon', Evangelical Quarterly 79(4), 311-329.

Morgan, R.L., 1957, 'Fulfilment in the Fourth Gospel: The Old Testament foundations: An exposition of John 17', Interpretation 11(2), 155-165. http://dx.doi org/10.1177/002096435701100202

Newman, B.M. \& Nida, E.A., 1993, A handbook on the Gospel of John, United Bible Societies, New York.

Pentiuc, E.J., 2002, 'The Christological interpretation of the Old Testament: A critical review', Greek Orthodox Theological Review 47(1/4), 37-54. 
Phillips, P.M., 2006, The prologue of the fourth gospel: A sequential reading, T\&T Clark, London. (Library of New Testament Studies 294).

Ridderbos, H., 1991, The gospel of John: A theological commentary, Eerdmans, Grand Rapids.

Rivkin, E., 1984, What crucified Jesus, Abingdon Press, Nashville.

Roth, W., 1987, 'Scriptural coding in the fourth gospel', Biblical Research 32, 6-29.

Sanders, E.P., 1989, 'Puzzling out Rabbinic Judaism', in W.S. Green (ed.), Approaches to Ancient Judaism, vol 2, pp. 65-80, Scholars Press, Missoula.

Sanders, J.A., 1975, 'Torah and Christ', Interpretation 29(4), 372-390. http://dx.doi org $/ 10.1177 / 002096437502900403$

Schnackenburg, R., 1968, The gospel according to John, Burns \& Oates, New York. (Herder, vol. 1).

Schneiders, S.M., 2002, 'Biblical spirituality', Interpretation 56(2), 133-142. http:// dx.doi.org/10.1177/002096430005600202

Schneiders, S.M., 2000, 'Spirituality in the academy', in K.J. Collins (ed.), Exploring Christian spirituality. An ecumenical reader, pp. 249-270, Baker Books, Grand Rapids.

Smith, H., 1962, 'Exodus typology in the fourth gospel', Journal of Biblical Literature $81,329-342$.

Steyn, G.J., 2012, 'Pauls's interpretation of Yehoshua ben Yoseph through the Scriptures of Israel as "retrodiction"', inaugural paper at the University of Pretoria, Pretoria, 27 August 2012.

Tenney, M.C., 1963a, 'The symphonic structure of John', Bibliotheca Sacra 120(478), $117-125$
Tenney, M.C., 1963b, 'The Old Testament and the fourth gospel', Bibliotheca Sacra $120(480), 300-308$.

Van der Watt, J.G., 1991, 'Die Woord het Mens geword: 'n Strukturele uiteensetting van die teologie van die Johannesevangelie', in J.H. Roberts, W.S. Vorster, J.N.
Vorster \& J.G. Van der Watt (reds.), Teologie in konteks, bl. 93-126, Orion, Halfway House.

Warden, F.M., 1953, 'God's only Son', Review \& Expositor 50(2), 216-223.

Westermann, C., 1968, Das Alte Testament und Jesus Christus, Calwer Verlag, Stuttgart. PMCid:PMC1703513

Westermann, C., 1994, Das Johannesevangelium aus der Sicht des Alten Testaments, Calwer Verlag, Stuttgart.

Weltzen, H., 2011, 'Exegetical analyses and spiritual readings of the story of the annunciation (Luke 1:26-38)', in P.G.R. de Villiers \& L.K. Pietersen (guest eds.), The Spirit that inspires: Perspectives on Biblical Spirituality, pp. 21-36, SUN MeDIA Bloemfontein. (Acta Theologica, Supplementum 15).

Wolfgang, R., 1987, 'Scriptural coding in the fourth gospel', Biblical Research 32, 6-29.

Wright, T.J., 2005, 'How is Christ present to the world?', International Journa of Systematic Theology 7(3), 300-315. http://dx.doi.org/10.1111/j.14682400.2005.00168.x

Wucherpfennig, A., 2003, 'Tora und Evangelium', Stimmen der Zeit 221(7), 486-494, viewed 07 November 2012, from http:// www.sankt-georgen.de/leseraum/ wucherpfennig1.pdf 